\title{
PENGARUH BEBERAPA EKSTRAK TANAMAN TERHADAP PENYAKIT BULAI PADA JAGUNG MANIS (Zea mays saccharata)
}

\author{
Winda Giofanny, Joko Prasetyo \& Efri \\ Jurusan Agroteknologi, Fakultas Pertanian Universitas Lampung \\ Jl. Prof. Soemantri Brodjonegoro, No. 1, Bandar Lampung 35145 \\ E-mail:Wgiofanny@yahoo.com
}

\begin{abstract}
ABSTRAK
Penyakit bulai merupakan penyakit utama tanaman jagung di Indonesia. Alternatif pengendalian penyakit yang mulai dikembangkan adalah penggunaan fungisida nabati. Penelitian ini bertujuan untuk mengetahui pengaruh ekstrak daun cengkeh, daun mengkudu dan bawang putih untuk menekan keterjadiaan penyakit bulai pada tanaman jagung manis. Penelitian ini disusun berdasarkan Rancangan Acak Kelompok (RAK) dengan lima perlakuan dan lima ulangan. Perlakuan terdiri atas ekstrak daun cengkeh, daun mengkudu, bawang putih dan fungisida metalaksil. Persentase keterjadian penyakit bulai yang diperoleh dianalisis dengan sidik ragam dan dilanjutkan dengan uji beda nyata terkecil (BNT) pada taraf $5 \%$. Hasil penelitian menunjukkan bahwa aplikasi ekstrak daun cengkeh, daun mengkudu dan bawang putih efektif dalam menekan keterjadian penyakit bulai dan lebih efektif dibandingkan aplikasi fungisida metalaksil. Ekstrak daun mengkudu dan bawang putih lebih efektif dibandingkan dengan ekstrak daun cengkeh dan fungisida pembanding.
\end{abstract}

Kata kunci : Ekstrak bawang putih, ekstrak daun cengkeh, ekstrak daun mengkudu, Peronosclerospora maydis.

\section{PENDAHULUAN}

Tanaman jagung manis merupakan jenis jagung yang belum lama dikenal dan baru dikembangkan di Indonesia. Jagung manis semakin populer dan banyak dikonsumsi karena memiliki rasa yang lebih manis dibandingkan jagung biasa. Selain itu umur produksinya lebih singkat yaitu $70-80$ hari sehingga sangat menguntungkan, namun tanaman jagung manis lebih rentan terserang hama dan patogen (Pou dkk., 2006).

Penyakit bulai merupakan penyakit utama tanaman jagung yang paling sering menginfeksi tanaman jagung di Indonesia. Kerusakan akibat penyakit bulai dapat mencapai $100 \%$ pada varietas jagung yang rentan (Burhanuddin, 2007). Peronosclerospora maydis merupakan penyebab penyakit bulai yang cukup berbahaya karena dapat menyebabkan kehilangan hasil hingga $100 \%$ atau puso seperti yang pernah terjadi di Lampung pada tahun 1996 (Subandi dkk., 1996).

Usaha pengendalian telah banyak dilakukan untuk mengatasi penyakit tersebut. Pengendalian secara kultur teknis yaitu mengusahakan jarak tanam yang tidak terlalu rapat dan menanam dengan menggunakan varietas tahan. Pengendalian secara mekanik dilakukan dengan mencabut tanaman yang terserang walaupun ukurannya masih kecil serta membakar tanaman sakit yang telah dikumpulkan. Pengendalian secara kimiawi dengan penggunaan fungisida ridomil yang berbahan aktif metalaksil pada tahun 80-an efektif mengendalikan penyakit bulai, namun berdasarkan penelitian yang dilakukan Burhanuddin (2009), penggunaan fungisida berbahan aktif metalaksil secara terus-menerus dalam jangka waktu lama akan menimbulkan resistensi $P$. maydis. Hal tersebut merupakan indikasi telah terjadinya perubahan ketahanan yang meningkat dari Peronosclerospora penyebab penyakit bulai. Sehingga dapat disimpulkan bahwa fungisida metalaksil tidak lagi efektif digunakan dalam pengendalian penyakit bulai (Burhanuddin, 2009). Oleh karenanya komponen pengendalian bulai lainnya perlu dilakukan. Cara-cara pengendalian alternatif yang sekarang banyak dikembangkan adalah pemanfaatan ekstrak bahan tanaman sebagai fungisida nabati. Daun cengkeh, daun mengkudu dan bawang putih telah banyak diteliti dan diduga mempunyai kemampuan sebagai fungisida nabati.

Daun cengkeh mengandung eugenol yang dapat merusak sel cendawan sehingga akan mengganggu pertumbuhan dan perkembangan cendawan patogen (Novita, 2008). Daun mengkudu mengandung berbagai senyawa seperti arginine, asparatic acid, a-sitosterol, cystenin, cystine, glutamic acid, antraquinon, glikosida dan resin yang berfungsi sebagai anti mikroba 
(Efri, 2010), sedangkan bawang putih mengandung allisin dan diallil sulfida yang bermanfaat sebagai bakterisida dan fungisida. Dengan demikian diharapkan ketiga bahan tersebut dapat bermanfaat dalam menekan keterjadian penyakit bulai tanaman jagung manis (Sumetriani, 2009).

\section{BAHAN DAN METODE}

Penelitian ini dilaksanakan di kebun sekitar Laboratorium Hama dan Penyakit Tanaman, Fakultas Pertanian Universitas Lampung pada bulan Mei-Juli 2013. Penelitian ini disusun dalam Rancangan Acak Kelompok (RAK) yang terdiri dari lima perlakuan dan lima ulangan. Perlakuan terdiri atas kontrol (P0), ekstrak daun cengkeh (P2), ekstrak daun mengkudu (P3), ekstrak bawang putih (P4) dan fungisida metalaksil (P5). Penelitian ini menggunakan polibag sebanyak 25 buah dengan setiap polibag ditanam 5 benih jagung manis varietas Bonanza F1. Tata letak percobaan diacak dengan menggunakan undian. Data yang diperoleh akan dianalisis dengan sidik ragam (Anova). Nilai tengah masing-masing perlakuan diuji dengan uji Beda Nyata Terkecil (BNT) pada taraf nyata 5\%.

Penyiapan tanaman uji dimulai dengan menanam benih jagung manis di polibag berukuran $5 \mathrm{~kg}$ sebanyak 25 buah polibag dengan media tanam berupa campuran tanah dan pupuk kandang yang telah dihomogenkan dengan perbandingan 3:1 dan disusun berdasarkan masing-masing perlakuan. Setiap polibag ditanam 5 benih jagung manis sehingga total 125 tanaman jagung.

Pada penyiapan inokulum, bahan inokulasi diambil dari spora tanaman jagung yang sakit di Kebun tanaman Politeknik Negeri Lampung pada jam 5 pagi. Pengambilan spora $P$. maydis dilakukan dengan cara merendam daun jagung yang bergejala ke dalam air kemudian dikeruk bagian bawah permukaan daun yang terdapat spora hingga bercampur dengan air selanjutnya dihomogenkan menggunakan rotamixer sehingga didapatkan kerapatan spora (4 x $10^{2}$ spora/ $\left.\mathrm{ml}\right)$.

Dalam pembuatan ekstrak tanaman, daun cengkeh dan bawang putih diperoleh dari sekitar daerah nunyai sedangkan daun mengkudu diperoleh dari tanaman mengkudu di sekitar lingkungan Fakultas Pertanian, Universitas Lampung. Daun cengkeh dan daun mengkudu yang digunakan adalah daun yang berwarna hijau tua. Bawang putih yang digunakan adalah bawang putih yang telah dikupas kulitnya. Masingmasing bahan (daun cengkeh, daun mengkudu dan bawang putih) dibersihkan dan dicuci menggunakan akuades. Selanjutnya daun mengkudu, daun cengkeh dan bawang putih dikeringkan dalam oven pada suhu $50^{\circ} \mathrm{C}$ selama 36 jam. Kemudian masing-masing bahan diblender dan diayak untuk mendapatkan tepung yang halus. Masing-masing bahan tersebut ditimbang sebanyak 20 gram lalu ditambahkan dengan akuades steril sebanyak $100 \mathrm{ml}$, kemudian dihomogenkan selama 1 jam. Hasil homogenisasi tersebut disaring menggunakan saringan teh kemudian ditambahkan akuades steril hingga volumenya menjadi $100 \mathrm{ml}$, selanjutnya larutan ekstrak tersebut siap digunakan untuk aplikasi.

Aplikasi ekstrak tanaman dilakukan setiap 3 hari sekali selama 5 minggu pada sore hari. Aplikasi ekstrak tanaman pertama kali dilakukan pada tanggal 10 juni 2013 sehari sebelum dilakukannya inokulasi buatan menggunakan hand spayer. Setiap tanaman perpolibag disemprotkan sebanyak $20 \mathrm{ml}$ ekstrak tanaman menggunakan hand sprayer.

Inokulasi Peronosclerospora maydis yang dilakukan meliputi inokulasi alami dan inokulasi buatan. Inokulasi alami dilakukan dengan cara meletakkan tanaman jagung yang bergejala bulai sebanyak 7 polibag diantara tanaman uji bersamaan dengan pertama kalinya dilakukan inokulasi buatan, sedangkan inokulasi buatan pertama kali dilakukan pada tanggal 11 juni 2013. Inokulasi buatan ini dilakukan dengan cara menyemprotkan suspensi spora $P$. maydis yang telah disiapkan pada tanaman jagung. Inokulasi buatan ini dilakukan setiap hari pada pukul 2 pagi. Pada penyiapan Suspensi Fungisida Metalaksil, bubuk fungisida ridomil berbahan aktif metalaksil ditimbang sebanyak 5 gram dan dilarutkan dalam 7,5 liter air, kemudian larutan tersebut disemprotkan sebanyak $20 \mathrm{ml}$ pada tanaman jagung perpolibagnya. Aplikasi fungisida metalaksil ini dilakukan bersamaan dengan aplikasi ekstrak tanaman.

Pengamatan pertama dilakukan pada saat tanaman jagung berumur 1 hsi (hari setelah inokulasi) dan pengamatan selanjutnya dilakukan setiap 3 hari sekali secara berkala selama 5 minggu. Peubah yang diamati adalah waktu inkubasi, keterjadian penyakit, tinggi tanaman dan bobot kering tanaman. Keterjadian penyakit dihitung menggunakan rumus :

$$
K t=\frac{n}{N} \times 100 \%
$$

Keterangan :

$\mathrm{Kt}=$ Jumlah tanaman terinfeksi bulai dibagi jumlah tanaman seluruhnya.

\section{HASIL DAN PEMBAHASAN}

Pada penelitian ini gejala penyakit bulai pada tanaman jagung manis mulai terlihat pada 10 hsi (hari 
setelah inokulasi). Gejala awal yang terlihat berupa munculnya bercak klorosis kecil. Bercak berkembang menjadi jalur klorosis yang sejajar dengan tulang daun dan selanjutnya daun klorosis merata atau bergaris-garis. Selanjutnya terjadi gejala sistemik dimana tanaman menjadi kerdil dan daun menjadi kaku. Pada infeksi yang berat, seluruh bagian tanaman berwarna kuning pucat dan kemudian mati. Di waktu pagi hari pada sisi bawah daun terdapat lapisan beledu putih yang terdiri dari konidiofor dan konidium.

Masa Inkubasi Patogen. Masa inkubasi dihitung dari awal waktu inokulasi sampai tanaman bergejala penyakit bulai. Berdasarkan hasil pengamatan, ratarata masa inkubasi muncul antara 10-11 hsi (Tabel 1). Keterjadian Penyakit. Keterjadian penyakit dilihat dari daun tanaman jagung yang terinfeksi bulai. Hasil analisis ragam data keterjadian penyakit bulai jagung manis menunjukkan bahwa aplikasi ekstrak tanaman berpengaruh nyata terhadap keterjadian penyakit bulai pada 2-5 msi (minggu setelah inokulasi), kecuali perlakuan ekstrak daun cengkeh yang tidak berpengaruh nyata pada pengamatan minggu ke-5 (Tabel 2).

Keterjadian penyakit bulai pada tanaman jagung manis meningkat pada setiap hari pengamatan. Dilihat dari grafik perkembangan keterjadian penyakit bulai (Gambar 1) bahwa pada pengamatan 3-33 hsi keterjadian penyakit bulai yang diberi perlakuan ekstrak

Tabel 1. Masa inkubasi muncul

\begin{tabular}{lc}
\hline Perlakuan & Massa inkubasi (hari) \\
\hline Kontrol (P0) & 10 \\
Cengkeh (P1) & 11 \\
Mengkudu (P2) & 10 \\
Bawang Putih (P3) & 12 \\
F.Sintetik (P4) & 10 \\
\hline
\end{tabular}

tanaman dan fungisida metalaksil lebih rendah dibandingkan keterjadian penyakit bulai pada kontrol, kecuali ekstrak daun cengkeh pada 35 hsi yang mengalami penurunan keefektifan sehingga pada akhir pengamatan ekstrak daun cengkeh tidak lagi efektif dalam menekan keterjadian penyakit bulai. Ekstrak daun mengkudu dan bawang putih pada 35 hsi sama efektifnya dalam menekan keterjadian penyakit bulai namun lebih efektif dibandingkan fungisida metalaksil.

Tinggi Tanaman. Tinggi tanaman jagung diamati pada 1 hsi (hari setelah inokulasi) dari pangkal batang dekat permukaan tanah sampai ujung daun yang paling tinggi. Hasil analisis ragam tinggi tanaman pada berbagai perlakuan tidak nyata (Tabel 3). Sehingga aplikasi berbagai perlakuan yang diberikan pada tanaman jagung tidak berpengaruh terhadap tinggi tanaman. Bobot basah dan kering tanaman. Hasil pengamatan dan analisis ragam bobot basah dan kering tanaman menunjukkan bahwa perlakuan ekstrak daun cengkeh, daun mengkudu dan bawang putih tidak nyata (Tabel 4), sehingga berbagai perlakuan yang diaplikasikan pada tanaman jagung tidak berpengaruh terhadap bobot basah dan kering tanaman.

Berdasarkan hasil penelitian, aplikasi ekstrak tanaman hanya berpengaruh nyata terhadap keterjadian penyakit bulai namun tidak berpengaruh nyata terhadap tinggi, masa inkubasi patogen dan bobot kering tanaman. Ekstrak tanaman (daun cengkeh, daun mengkudu dan bawang putih) dapat menekan keterjadian penyakit bulai. Hal ini disebabkan ekstrak tanaman mengandung beberapa senyawa kimia yang dapat menekan pertumbuhan cendawan (Zaidun, 2006). Salah satu senyawa kimia tersebut adalah eugenol yang terkandung didalam daun cengkeh. Seperti yang dikemukakan Novita (2008) bahwa daun cengkeh mengandung senyawa eugenol yang dapat merusak sel cendawan sehingga akan mengganggu pertumbuhan dan perkembangan cendawan patogen, namun pada hasil

Tabel 2. Rerata Keterjadian Penyakit pada 2-5 msi

\begin{tabular}{lcccc}
\hline \multirow{2}{*}{ Perlakuan } & \multicolumn{4}{c}{ Keterjadian Penyakit (\%) } \\
\cline { 2 - 5 } & $2 \mathrm{msi}$ & $3 \mathrm{msi}$ & $4 \mathrm{msi}$ & $5 \mathrm{msi}$ \\
\hline Kontrol(P0) & $31,60 \mathrm{a}$ & $83,20 \mathrm{a}$ & $83,20 \mathrm{a}$ & $88,20 \mathrm{a}$ \\
Cengkeh (P1) & $4,00 \mathrm{c}$ & $48,00 \mathrm{c}$ & $68,00 \mathrm{~b}$ & $84,00 \mathrm{a}$ \\
Mengkudu (P2) & $12,32 \mathrm{~b}$ & $30,32 \mathrm{~d}$ & $43,32 \mathrm{~d}$ & $54,60 \mathrm{c}$ \\
Bawang Putih (P3) & $4,00 \mathrm{c}$ & $43,60 \mathrm{c}$ & $54,00 \mathrm{c}$ & $58,00 \mathrm{c}$ \\
F.Sintetik (P4) & $15,00 \mathrm{~b}$ & $56,00 \mathrm{~b}$ & $56,00 \mathrm{c}$ & $79,56 \mathrm{~b}$ \\
\hline
\end{tabular}

Keterangan: Angka dalam kolom yang diikuti huruf berbeda menunjukkan perbedaan yang nyata pada uji BNT taraf $5 \%, \mathrm{msi}=$ minggu setelah inokulasi. 


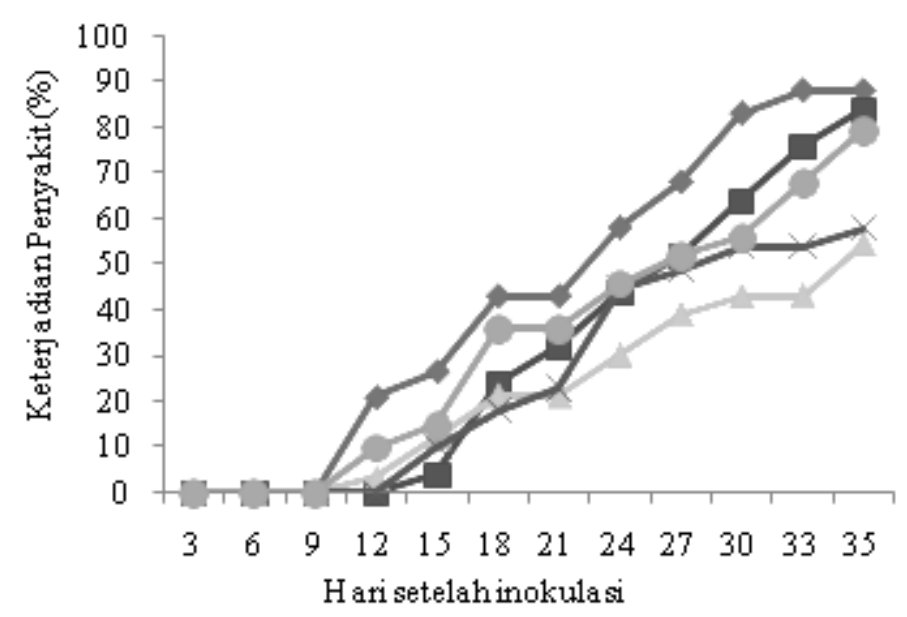

Gambar 1. Perkembangan keterjadian penyakit bulai berbagai perlakuan, $\bullet=$ kontrol, $\mathbf{\square}=$ daun cengkeh, $\Delta=$ daun mengkudu, $\times=$ bawang putih, $\bullet=$ fungisida metalaksil.

Tabel 3. Rerata tinggi tanaman $(\mathrm{cm})$ dari 1-5 msi

\begin{tabular}{lccccc}
\hline \multirow{2}{*}{ Perlakuan } & \multicolumn{5}{c}{ Tinggi tanaman (cm) } \\
\cline { 2 - 6 } & $1 \mathrm{msi}$ & $2 \mathrm{msi}$ & $3 \mathrm{msi}$ & $4 \mathrm{msi}$ & $5 \mathrm{msi}$ \\
\hline Kontrol (P0) & 9,87 & 23,44 & 34,87 & 42,52 & 49,10 \\
Cengkeh (P1) & 10,73 & 24,13 & 36,99 & 47,54 & 55,91 \\
Mengkudu (P2) & 9,47 & 21,42 & 34,50 & 45,20 & 55,16 \\
Bawang Putih (P3) & 11,48 & 26,15 & 41,22 & 53,17 & 60,58 \\
F.Sintetik (P4) & 11,87 & 27,70 & 40,61 & 50,28 & 58,22 \\
\hline F hitung & $1,24 \mathrm{tn}$ & $2,38 \mathrm{tn}$ & $2,59 \mathrm{tn}$ & $2,78 \mathrm{tn}$ & $1,75 \mathrm{tn}$ \\
\hline
\end{tabular}

Keterangan $: \mathrm{tn}=$ tidak berbeda nyata pada taraf $5 \%$, msi $=$ minggu setelah inokulasi.

Tabel 4. Bobot basah dan bobot kering tanaman

\begin{tabular}{lcc}
\hline Perlakuan & Bobot basah (gram) & Bobot kering (gram) \\
\hline Kontrol (P0) & 42,17 & 19,44 \\
Cengkeh (P1) & 46,81 & 20,22 \\
Mengkudu (P2) & 44,95 & 20,05 \\
Bawang Putih (P3) & 51,65 & 21,36 \\
Funngisida Sintetik (P4) & 49,70 & 22,01 \\
\hline F hitung & 2,13 tn & 2,12 tn \\
\hline
\end{tabular}

Keterangan $:$ tn $=$ tidak berbeda nyata pada taraf $5 \%$.

penelitian didapat bahwa ekstrak daun cengkeh tidak dapat menekan keterjadian penyakit bulai pada pengamatan terakhir, hal tersebut dapat dikarenakan senyawa eugenol yang terkandung didalam daun cengkeh mudah menguap (Novita, 2008), sehingga tidak dapat terikat kuat pada tanaman.

Adanya penekanan dari ekstrak daun mengkudu terhadap keterjadian penyakit bulai disebabkan kandungan beberapa senyawa, seperti arginine, asparatic acid, a-sitosterol, cystenin, cystine, glutamic acid, terutama senyawa-senyawa aktif antara lain antraquinon, glikosida dan resin yang merupakan senyawa alkaloid dan bersifat antifungi maupun antimikroba (Djauhariya dkk., 2006 dalam Eka dkk., 2013).

Hal ini dibuktikan dengan penelitian Jayaraman dkk. (2008) dalam Efri (2010) bahwa senyawa-senyawa yang terkandung didalam ekstrak daun mengkudu 
mampu menghambat pertumbuhan jamur Penicillium, Fusarium, Rhizopus dan Mucor mendekati 50\%. Penggunaan ekstrak daun mengkudu juga dilaporkan oleh Efri (2010) efektif menekan perkembangan keterjadian dan keparahan penyakit antraknosa (Colletrotichum capsici) pada tanaman cabai. Sehingga ekstrak daun mengkudu memiliki kemampuan untuk menekan keterjadian penyakit bulai pada jagung manis.

Ekstrak bawang putih efektif dalam menekan keterjadian penyakit bulai dikarenakan kandungan allisin dan diallil sulfida pada bawang putih yang bermanfaat sebagai bakterisida dan fungisida. Hal ini diperkuat oleh penelitian Rukmana (1995) dalam Sumetriani (2009), bahwa senyawa allisin yang terkandung didalambawang putih sangat efektif dalam menghambat perkembangan cendawan Penicillium sp. khususnya P. corymbiferum.

Perlakuan ekstrak tanaman yang memberikan pengaruh penekanan yang paling tinggi terhadap keterjadian penyakit bulai jagung manis adalah ekstrak daun mengkudu dan ekstrak bawang putih. Hal ini dikarenakan kandungan senyawa alkaloid yang terkandung didalam daun mengkudu seperti antraquinon, glikosida dan resin lebih kuat dalam menghambat pertumbuhan $P$. maydis dibandingkan senyawa aktif yang terkandung didalam ekstrak daun cengkeh. Selain itu senyawa-senyawa yang tergolong dalam alkaloid memiliki sifat antimikroba yang dapat menghambat pertumbuhan beberapa jamur. Komponen kimia senyawa alkaloid seperti antraquinon, glikosida dan resin yang bersifat antifungal mampu menembus dinding sel jamur, dengan demikian akan terjadi gangguan proses metabolisme di dalam sel sehingga akan mengganggu pertumbuhan sel dan pada konsentrasi tertentu akan berakibat kematian pada sel jamur (Knobloch dkk., 1989 dalam Eka dkk., 2013). Sedangkan pada bawang putih, kandungan allisin dan dialil sulfida memiliki mekanisme molekuler yang dapat memblokade aktifitas enzim cysteine proteinase pada jamur yang merupakan penyebab utama infeksi dan gangguan metabolisme tanaman, selain itu allisin dan diallil sulfida juga dapat menghambat aktifitas jamur dan virus (Solihin, 2009) sehingga ekstrak daun cengkeh dan bawang putih efektif dalam menekan keterjadian penyakit bulai.

Pada penelitian ini juga digunakan fungisida berbahan aktif metalaksil $(5 \mathrm{~g} / 7,5 \mathrm{ml})$ sebagai pembanding. Berdasarkan hasil penelitian, fungisida metalaksil efektif menekan keterjadian penyakit bulai namun tidak lebih efektif dibandingkan dengan perlakuan ekstrak daun mengkudu dan bawang putih. Dengan demikian fungisida nabati ekstrak tersebut lebih baik dibandingkan fungisida metalaksil karena aman dan ramah terhadap lingkungan serta tidak menyebabkan resistensi pada patogen. Seperti yang dilaporkan Burhanuddin (2009) penggunaan fungisida berbahan aktif metalaksil secara terus menerus telah menyebabkan resistensi $P$. maydis di kabupaten Bengkayang, Kalimantan Barat. Selain itu, kurang efektifnya fungisida metalaksil dapat disebabkan karena umur kemasan yang sudah lama.

Pada hasil penelitian terlihat tidak adanya perbedaan yang berarti dari bobot basah dan bobot kering antara tanaman yang diberi perlakuan ekstrak tanaman dan fungisida metalaksil dengan tanaman tanpa perlakuan atau kontrol. Hal tersebut diduga sifat toleran tanaman mampu menyesuaikan diri dengan patogen yang berkembang di jaringan tubuhnya sehingga jaringan tanaman yang rusak dapat tumbuh kembali., dengan demikian tanaman dapat terus tumbuh meskipun telah terinfeksi P. maydis.

\section{KESIMPULAN}

Dari hasil penelitian yang telah dilakukan dapat disimpulkan bahwa ekstrak daun cengkeh, ekstrak daun mengkudu dan ekstrak bawang putih efektif dalam menekan keterjadian penyakit bulai. Ekstrak daun mengkudu dan bawang putih paling efektif dalam menekan keterjadian penyakit bulai. Ekstrak daun mengkudu dan bawang putih memiliki efektifitas yang sama dan lebih efektif menekan keterjadian penyakit bulai dibandingkan fungisida pembanding.

\section{DAFTAR PUSTAKA}

Aak. 1997. Teknik Bercocok Tanam Jagung. Kanisius. Yogyakarta.

Asman, A., M. Tombe, dan Manohara, D. 1997. Peluang Penggunaan Produk Cengkeh sebagai Pestisida Nabati. Monografi Tanaman Cengkeh Ke-2. Balai Penelitian Tanaman Rempah dan Obat. Bogor.

Burhanuddin. 2007. Penyakit Karat Puccinia polysora (Uredinales: Pucciniaceae) Pada Tanaman Jagung. Prosiding Seminar Ilmiah dan Pertemuan Tahunan PEI dan PFI XVIII Komda Sul-Sel 200. Hal : 281-289.

Burhanuddin. 2009. Fungisida Metalaksil Tidak Efektif Menekan Penyakit Bulai (Peronosclerospora maydis) di Kalimantan Barat dan Alternatif Pengendaliannya. Prosiding Seminar Nasional 
Serealia 2009. Balai Penelitian Tanaman Serealia, hlm 395-399.

Daherba. 2011. Mengkudu. http://www.deherba.com/ khasiat-mengkudu.html. Di akses pada tanggal : 27 September 2012.

Dongoran, D. 2009. Respon Pertumbuhan dan Produksi Tanaman Jagung Manis Terhadap Pemberian Pupuk Cair TNF dan Pupuk Kandang. http://repository.usu.ac.id/bitstream/ 123456789/7561/1/09E02128.pdf. Di akses pada tanggal : 27 September 2012.

Efri. 2010. Pengaruh Ekstrak Berbagai Bagian Tanaman Mengkudu (Morinda citrifolia) Terhadap Perkembangan Penyakit Antraknosa Pada Tanaman Cabai (Capsicum anuun. L). Jurnal Hama Penyakit dan Tumbuhan Tropika. 10(1): 52-58.

Eka, S., Efri dan J. Prasetyo. 2013. Pengaruh Berbagai Tingkat Fraksi Ekstrak Daun Mengkudu (Morinda citrifolia L) Terhadap Pertumbuhan Colletrotichum capsici Penyebab Penyakit Antraknosa Pada Cabai (Capsicum anuum L) Secara In Vitro. Jurnal Agrotek Tropika. 1(1): 92-97.

Fitriani, F. 2009. Hama dan Penyakit Jagung Manis (Zea mays saccharata Sturt.) di Desa Benteng, Cibanteng dan Nagrog, Kecamatan Ciampea, Kabupaten Bogor, Jawa Barat. (Skripsi). Departemen Proteksi Tanaman Fakultas Pertanian, Institut Pertanian Bogor. Bogor.

Mujim, S. 2009. Efikasi ekstraks air daun cengkeh dalam penekanan perkembangan Drechslera maydis in vitro. Jurnal Hama Penyakit dan Tumbuhan Tropika. 9(1): 78-82.

Novita, T. 2008. Peran Daun Cengkeh Terhadap Layu Fusarium Pada Tanaman Tomat. Jurnal Agronomi. 12(2): 14-17.

Oka, I.N. 1993. Pengantar Epidemiologi Penyakit Tanaman. Yogyakarta: Gadjahmada University Press.

Pou, E. Achmad, G dan Wahab, A. 2006. Tingkat Adopsi Inovasi Petani Terhadap Teknologi Budidaya Jagung Manis Di Kelurahan Borongloe, Kecamatan Bontomarranu, Kabupaten Goa. Jurnal Agrisistem. 2(2): 85-92.
Semangun, H. 2006. Pengantar Ilmu Penyakit Tumbuhan. Yogyakarta: Gajah Mada University Press.

Semangun, H. 2004. Penyakit-penyakit Tanaman Pangan di Indonesia. Gajah Mada University Press

Sibarani, F. 2008. Uji Beberapa Pestisida Nabati Untuk Mengendalikan Penyakit Antraknosa Pada Cabai (Capsicum annuum L) di Lapangan. (Skripsi). Universitas Sumatera Utara, Fakultas Pertanian. Sumatera Utara.

Solihin. 2009. Manfaat Bawang Putih. Media Management. Jakarta.

Subandi, M. Sudjadi, dan D. Pasaribu. 1996. Laporan Hasil Pemantauan Penyakit Bulai dan Benih Palsu Pada Pertanaman Jagung Hibrida di Lampung. Lampung.

Sumetriani, M. 2009. Efektifitas Ekstrak Bawang Putih (Allium sativum L) Dalam Menghambat Pertumbuhan Jamur Legenidium sp. Penyebab Penyakit Pada Abalon. (Thesis). Universitas Udayana, Fakultas Matematika dan Ilmu Pengetahuan Alam.

Surtikanti. 2012. Penyakit Bulai Pada Tanaman Jagung. Jurnal Balai Penelitian Tanaman Serealia. 2(1): 41-48.

Waha, L. G. 2001. Sehat Dengan Mengkudu. MSF Group. Jakarta.

Wijayakusuma, H. 1994. Tanaman Berkhasiat Obat di Indonesia. Pustaka Kartini. Jakarta.

Wiratno. 2009. Cengkih berpotensi sebagai pestisida nabati. Warta Penelitian dan Pengembangan Pertanian.

Zaidun. 2006. Bahan Tumbuhan Rawa yang Berpotensi Sebagai Fungisida Nabati. Temu Teknis Nasional Tenaga Fungsional Pertanian 2006. Kalimantan Selatan. 